\title{
Epistemology of a New Era of Healthy Foods and the Construction of Social Myths \\ José Luis Martínez
}

Diplomatic Mexican to UNESCO, 1 rue Miollis, 75015, Paris, France

\section{Abstract}

The epistemology of food is my proposal to elucidate the forms of creation of scientific and nonscientific knowledge about the food phenomenon. From the rhetoric emanating from scientific discourses and in their dissemination, it is worth analyzing the construction of myths, paradigms, and popular distortions in the daily life of the individual. New paradigms, scientific discoveries, are often disseminated in a deterministic manner, reducing the knowledge. These disclosures sometimes commercial, generate a complexity of reactions in society concerning the scientific task. The social construction of science is also an identity crisis in modern societies. Then, from the food option of the individual, how identities are constructed, and this identity is also associated with manifestations of the state of health. However, an individual has access to food related to certain socio-economic conditions and cultural conditions specific to their geopolitical origin. Nowadays, talking about food is linked to thinking about health, nutrition, economy, environment, but it is also necessary to talk about the right to food. This raises, approximately, sustainable public policies to guarantee the right to "eat healthily" and "culturally appropriate. Discussing a cultural notion of food and introducing it to the biological and economic notion of food leads us to rethink the phenomenon of food from science and nutrition.

\section{Introduction}

The food crisis beyond being a multidimensional pragmatic problem, is a crisis of interpretation and knowledge about the food notion, therefore it is an epistemological phenomenon [1-3]. From in traditional perspective, the food crisis has two nuances, the first is related to economic and geopolitical situations, mainly with consequences such as famines, droughts, climate change, food security, access, and development of technologies. In this first nuance, the biotechnology sciences were proposed as solutions and had a great impulse in the past decades, to generate solutions from the agro-economy, together with the development of large industrial consortiums of food, also driven by free-market economic policies, based on efficiency, productivity and high performance [4,5]. In counterpart to the accelerated growth of the food industry, it is linked to the increase in the consumption of hypercaloric foods and with alterations in health, such as malnutrition, obesity, diabetes, metabolic syndromes, cardiovascular diseases, mental disorders. These alterations lead to the second nuance related to the health of the food crisis. Scientific advances in the fields of nutrition, food science, microbiology, and genomics have answered these questions, influenced by the search for healthy food [5-8]. However, the social perceptions about healthy food terms contain knowledge and notion that emerged in the history of the individual $[9,10,6]$, and the cultural context, traditions, familiar custom, religion, cosmogony, and ecological $[11,12]$.These two notions about the food crisis can be complemented with the construction of myths, as a product of the natural social dynamics and the perception of the construction of knowledge from the scientific bases to common sense [13-15,6]. Consequently, the construction of social myths about foods allows them to be integrated into the cultural identity, the ecological identity, and the culinary identity. The discussion here is research towards an epistemology of food, based on deconstruction and from complex thought, resulting in the neologism Ecofoodomics.

\section{Theoretical Principles towards an Epistemology of Food}

\section{The deconstruction as a strategics of food epistemology}

Deconstruction consists of dissociation for analysis of how any concept has been built from historical processes and accumulations of thoughts of the signifier [16]. Affirming that any type of text is presented not only as a phenomenon of communication but also of significance. Revealing that the clear and evident differs from being so since the truth in itself depends on the historical, the relative and is frequently subjected to the paradoxes of the rhetorical figures of metaphor and metonymy $[16,17]$. Deconstruction is not a method, it is a strategy, a new reading practice. It investigates the conditions of possibility of the concepts, but it should not be confused with a search for the transcendental conditions of the possibility of knowledge $[18,19]$. Deconstruction revises and dissolves imposition in an absolute denial of meaning but does not propose an alternative organic model $[18,16]$. Deconstructing consists of decomposing something that has been erected, elaborated into verifying how that something is made, how its pieces are articulated, what are the hidden layers that constitute it. The deconstruction away from the approach of a skeptical operation of the construction of knowledge tries assuming in a positive way to face renouncing a supposed universality and to accept the subtility of the construction of what is understood as knowledge or meaning of what it represents as knowledge. Deconstruction consists of analyzing the scientific and non-scientific literature, breaking down the parts that make it up to understand the use of related terminologies in a given context, such as food $[19,20,17]$.

*Corresponding Author: Dr. José Luis Martínez, Diplomatic Mexican to UNESCO 1 rue Miollis, 75015, Paris, France; E-mail: mjoseluis@gmx.com

Citation: Martínez JL (2021) Epistemology of a New Era of Healthy Foods and the Construction of Social Myths. Int J Clin Nutr Diet 7: 158. doi: https://doi. org/10.15344/2456-8171/2021/158

Copyright: (c) 2021 Martínez. This is an open-access article distributed under the terms of the Creative Commons Attribution License, which permits unrestricted use, distribution, and reproduction in any medium, provided the original author and source are credited. 


\section{Epistemology of foodfrom complexity}

In the conventional approach in sciences, there is a gap in the construction of knowledge because is supported from the binary perspective of reality, this is the "cause and effect" principle or linear thinking $[21,13]$. Then reality is a set of disconnected parts, interpreted between borders and hanging bridges. Nevertheless, reality refers to complex systems and problems; it is dynamic and multidimensional and consists of a collection of interconnected relationships nonlinearity. Then, the principles of complexity thought into the science refer to the ability to interconnect different dimensions of reality. Complexity thought tries to describe and explain the problems that arise from the difficulty of perceiving reality from functional isolated units. Therefore, complex thinking addresses a comprehensive understanding of reality, which is conceived as the link between different realities $[15,14,13]$.

The notion of food from complexity can be exemplified by deconstructing the meaning of bread, then we can deconstruct three levels of representation of the meaning of bread.

The first is biological as a nutrient: the content of carbohydrates, yeasts, salts, fibers; gluten. Then a second perception about Bread's economic perception: conditions of the agriculture of grains, varieties of grains, transgenic technology, grain treatment, milling, flour, fermentation, cost, sale, packaging, process. The third notion, meaning, or representation about Bread can be like the traditional or cultural: the baguette in France or the bolillo bread in Mexico, the unleavened bread for religious rituals in religions. Then a Bread can be culinary identity element with local know-how. These threelevel perceptions of reality about Bread, are a problem of complexity because confronting the three realities of the parts and linking them in a single conceptual unit.

In this sense, the theory of complexity leads to reflect on the construction of knowledge about the food to propose a deeper scope. Science makes sense with the established hypothesis, controlling the phenomenon, measuring, falsified, stratified, but loses sense when faced with the social-anthropological notion of food. In addition, the subjectivity of the scientist also contributes to the complexity [22], because he is also an anthropological and cultural actor, linked to social paradigms [13]. These actors at the same time structure research hypotheses, academic frameworks that are presented as the results of a global nutritional-food problem, but to respond to local-particular demands. Science within the food phenomenon faces challenges of the new reality of knowledge of complexity. Then a food epistemology from complexity proposes to be discussed and raised.

\section{The Epistemic Food Notions}

The epistemic food notion can be approached from the node of complexity in three notions that are discussed below.

\section{The foodbiological notion}

Given the human species, life is understood as vulnerable biochemical machinery $[5,7,23]$. Food is itself a notion that has a broad physical-chemical-biological meaning and focuses on the potentiality and continuity of life. This approach is broad, first comprising the chemical composition of food in biomolecules: lipids, carbohydrates, and proteins, in addition to minerals. Next, the function of these molecules in metabolic processes and the balance of matter and energy in the body. Finally, the effects of these on health and add a new concept that involves an ecological scope, the gut microbiota $[8,10,24]$.
Advances in science have proposed new terms in food such as functional food, probiotics, prebiotics, gut microbiota, that arise from scientific research in the field of microbiology, nutrigenomics, and proteomics, modifying the perception of food in consumers $[25,26,6]$. The new scientific language is often disclosed with distortions in its meaning, resulting in interpretations leading to myths about the effect of food on health $[27,28,14,5,29,22]$. This is a consequence of a vision based on the cause-effect of scientific research [14,21]. The results of the investigations are often interpreted in metaphors, to bring the information closer to the public $[17,30,14,9]$. In this information, biases are created, for example, that all lactic bacteria is itself a probiotic because it is present in yogurt [28]. Or, consider lipids as negative in their consumption for health [31]. Finally, the nutrigenomic notion of food is frequently linked to genetic predisposition and human races, which can be a bias with a socially negative result [14]. The biologicalgenetic interpretation of life is based on mechanistic-functionality, biases in a biological reduction, ism, and deterministic results [13,21]. The complexity is then the Gordian knot of the biological notion of food, to show us a reality more linked to food notion with the result of the research itself.

\section{The food economic notion}

The second notion is the effect of the food as a product $[4,30,1]$. This represents the socio-economic notion, the criteria for evaluating food as a set of processes towards a good manufactory, a product, the means of production necessary for its transformation, conservation, and safety, which they are closely linked with policies in agriculture, economic planning, geopolitics, and land-ecological administration $[6,32,30]$. After the Second World War, the industrialization of the mass production of agriculture gave rise to the emergence of the so-called food sciences and technologies [6]. These sciences agreed on disciplines to standardize food production, the creation of international protocols based on the creation of packaged foods, preserved safe, but above all, from the food industry. Industrial mass production was focused on facilitating access and distribution of foods rich in fats and sugars -hypercaloric- to facilitate the calorific contribution and thus improve the performance during the eight working hours of the employees [10,2,7]. Thus, chains of fast-food companies were created, linked to decision-making in agricultural policies [30]. Large tracts of land were turned into agricultural fields and farms. Large investments were created in the universities linked to study programs to develop the necessary technologies with private capital. The science and technology of food was then the creation of capital towards standardization and high production [6]. The fastfood style quickly became a fashion, the speed in both its production processes, distribution, and easy access, made its ingredients rich in fat and sugars the basic diet of the workers and the most unprotected classes of north America [30,9,6]. This model began to be imported into Latin American and Asian countries with greater power than in other continents $[4,9,6]$. Cheap labor and the expansion of capitals were introduced with an important aspect, food as a category of identity. American fast food not only standardized its identity foods but did the same with foods from other countries [30,6].

\section{The foodcultural notion}

Food as a cultural notion represents the anthropological issues of food-nutrition, as an element of identity in communities and collectivities $[11,12,9]$. The mystical takes up the centrality overscience, and then the extremes between life and death create systems of complexity and understanding [13]. Life beyond the biologicalphysical-chemical is a mystery, it is mystical. In the first cultures, the 
mystery of life was associated with the totality and in that cosmogonic space the food takes back the centrality, the act of eating is linked to life. A human ritual with a thought based on the mystical $[9,33]$. In its epistemic meaning, food is interpreted as a purely subjective question and is disarticulated from the epistemic phenomenon of "scientific objectivity" and "socioeconomic reality" [21]. Food as an identity element, then as food, has been regaining strength in the sense of social resistance to the economic policies produced by global capital, the resistance of indigenous communities and diverse cultures in national states, basing the use of consumer rhetoric local as a response of struggle and resistance to foods considered fast-food, these symbolize or are interpreted as intruders in culinary cultural identities [34,30]. Hypercaloric foods emerge as scientific innovations in the sciences of food and nutrition that altered the customs of food consumption in the regions and countries where industrializations were created [35,36,31,10,7]. This industrial phenomenon altered customs in the consumption of local food, which had a sense of identity [35]. The food production system, based on high efficiency and scientific precision, offered smaller producers to introduce standardized practices and smaller-scale technologies, as long as they maintained the same models based on efficiency and control [35].

The uniformity of the food production processes was maintained, and the artisans lost their battle. Credits for financing the creation of small farms or small manufactures resorted to accepting the principles of large firms creating foods of different brands but essentially the same $[30,6]$. From the above, perhaps we should reflect on the following questions: Is there a cognitive or representative difference between a meal and food? industrially is a food distinguished from a meal? for a consumer what would be the difference between food or a meal?

Culturally a food makes sense when it is transformed into a meal. Epistemologically food and meals are distinguished. A pizza can be a food, if it is processed with technology, using ingredients that are the product of scientific knowledge of food science. While the pizza is a meal when it is prepared with ingredients and artisanal knowledge. The pizza can be the same element with two meanings for the same consumer, creating a system of myths around the representation of food meals. For example, pizzas are one of the foods that UNESCO has so far recognized among twenty-five food and drink-related traditions as part of its Representative List of the Intangible Cultural Heritage of Humanity (Table 1). According to UNESCO "Cultural heritage are all traditions or living expressions inherited from our ancestors and passed on to our descendants, such as oral traditions, performing arts, social practices, rituals, festive events, knowledge, and practices concerning nature and the universe or the knowledge and skills to produce traditional crafts".

\begin{tabular}{|c|c|}
\hline Representative List of the Intangible Cultural Heritage of Humanity, UNESCO & Country / Countries \\
\hline 1.Hawker culture in Singapore, community dining, and culinary practices in a multicultural urban context & Singapore \\
\hline 2.Il-Ftira, culinary art and culture of flattened sourdough bread in Malta & Malta \\
\hline 3.Knowledge, know-ho,w and practices about the production and consumption of couscous & Algeria - Mauritania - Morocco - Tunisia \\
\hline 4.Art of Neapolitan 'Pizzaiuolo' & Italy \\
\hline 5.Dolma making and sharing tradition, a marker of cultural identity & Azerbaijan \\
\hline 6.Nsima, the culinary tradition of Malawi & Malawi \\
\hline 7.Flatbread making and sharing culture: Lavash, Katyrma, Jupka, Yufka & $\begin{array}{l}\text { Azerbaijan - Iran (the Islamic Republic of) - } \\
\text { Kazakhstan - Kyrgyzstan - Turkey }\end{array}$ \\
\hline 8.Oshi Palav, a traditional meal and its social and cultural contexts in Tajikistan & Tajikistan \\
\hline 9.Palov culture and tradition & Uzbekistan \\
\hline 10.Arabic coffee, a symbol of generosity & $\begin{array}{l}\text { United Arab Emirates - Saudi Arabia - } \\
\text { Oman - Qatar }\end{array}$ \\
\hline 11.The tradition of kimchi-making in the Democratic People's Republic of Korea & Democratic People's $\quad$ Republic of Korea \\
\hline 12.Argan, practices, and know-how concerning the argan tree & Morocco \\
\hline 13.Lavash, the preparation, meaning, and appearance of traditional bread as an expression of culture in Armenia & Armenia \\
\hline 14.Ancient Georgian traditional Qvevri wine-making method & Georgia \\
\hline 15.Kimjang, making and sharing kimchi in the Republic of Korea & Republic of Korea \\
\hline 16.Mediterranean diet & $\begin{array}{l}\text { Cyprus - Croatia - Spain - Greece - Italy - } \\
\text { Morocco - Portugal }\end{array}$ \\
\hline 17.Turkish coffee culture and tradition & Turkey \\
\hline 18. Washoku, traditional dietary cultures of the Japanese, notably for the celebration of New Year & Japan \\
\hline 19.Ceremonial Keşkek tradition & Turkey \\
\hline 20.Gastronomic Meal of the French & France \\
\hline 21.Traditional Mexican cuisine - ancestral, ongoing community culture, the Michoacán paradigm & Mexico \\
\hline 22.Beer culture in Belgium & Belgium \\
\hline 23.The traditional technique of making Airag in Khokhuur and its associated customs & Mongolia \\
\hline 24.Practices and traditional knowledge of Terere in the culture of PohãÑana, Guaraní ancestral drink in Paraguay & Paraguay \\
\hline 25.Oshituthi shomagongo, marula fruit festival & Namibia \\
\hline
\end{tabular}


The yogurt is a good example of Cultural Heritage and this we can verify in two references a historical and cultural-religious. In Genesis 18:8 of the Persian version of the old testament "Abraham owed his longevity to the consumption of sour milk" and in 76 BC the Roman historian Plinius recommends the administration of fermented milk for the treatment of gastroenteritis [25]. In addition, yogurt is today a food that can contain probiotic bacteria and benefit health. In addition, yogurt is today a food that can contain probiotic bacteria and benefit health. Then, we can think that traditional knowledge of the consumption of food, which is the myth of having some benefit for health, thanks to today's science, has been validated. In this case, the food notion of culture makes sense and is linked to the biological food notion and this gives it a value to make the food a product, the economic notion of the food.

\section{Modern science at the service of tradition: Ecofoodomics}

Ecofoodomics is a neologism to rethink the science of food from a transdisciplinary perspective. It is to open the borders of conceptual frameworks of reductionism biologic to redefine the generation of knowledge and understanding of the food phenomenon.

The neologism foodomics was introduced as a holistic definition of sciences food and nutrition discipline that uses omics technologies to assess relevant aspects related to safety, quality, production, processing, and new ingredient design [26,37], to preserve sustainability minimizing the environmental impact [38]. Although foodomics as neologism linked to sustainability is more integral, maintains a conceptual framework into the cause-effect paradigm. Inside a food epistemological perspective discussed here, Ecofoodomics is introduced and proposed as a non-concept to rethink the science of food from a Complexity perspective. It is to open the borders of conceptual frameworks of reductionism biologic to redefine the generation of knowledge and understanding of the food phenomenon. The prefix Oikosos is to add a dimension of belonging to the individual to the collective, it is to remember that food is a socializing element, where the consumer gives meaning to his culture, spiritualizes it, food also an identity [33]. From Greek oikos-house, Aristotle describes the Oikos as a "community constituted naturally for the satisfaction of daily needs, whose members are defined as those who have been raised with the same food" [39]. A cup of coffee supposes maybe a certified organic bean, from local geography, is also know-how, pressure, and temperature, caffeine, infusion, cup, design, one moment to drink it, maybe to start a negotiation, to write this article, all these elements around a cup coffee is identity, a dialogue between food and individual into anthropological context, these elements together is Ecofoodomics.

Ecofoodomics is proposed as an epistemological tool, to build a non-concept, that integrates, that deconstructs, and at the same time releases other paradigms to give language to the phenomena inherent in the act of eating and its object the food.

\section{Conclusion}

Throughout history and depending on causal theory, the sciences have had a fundamental problem when terms are used from a scientific context to characterize a reality within another scientific context. From the philosophical thought, it goes back to the approaches of Thomas Hobbes (Leviathan), who points out that the human condition was derived from his understanding of human biology, being the biological inevitability that made men what they were.
So, the question is to extend the reductionist approach of biology to contribute to ensuring important factors that influence the appreciation of knowledge. In the food and nutrition sciences, there are deformations in the production of knowledge, where only the biological mechanistic that constitutes the belonging of man is considered, without taking into account the influence of his environment and culture (currently the microbiome advances add complexity to knowledge).

Food Epistemology is proposed to start the analysis from the complexity, which consists of a circle of knowledge that works by attracting each other and whose process allows conceiving the transdisciplinary reorganization of knowledge [40]. The link between complexity and deconstruction is proposed, on the one hand, refers to the investigated realities, a complexity of phenomena irreducible to a single dimension and whose meanings depend strongly on the context; and on the other, to the intellectual effort to understand them, through the elaboration of models that take into account the context. The progress of critical thinking is linked to the ability to react against the fragmentation of knowledge [15].

\section{Conflict of Interest}

The content of this article is an individual scientific contribution of the author and does not represent the opinion of the authority that he represents as a diplomat.

\section{References}

1. SWAC/OECD (2020) Food and Nutrition Crisis 2020, Analyses \& Responses. Maps \& Facts. OECD.

2. FAO, IFAD, UNICEF, WFP, WHO (2020) The State of Food Security and Nutrition in the World. The State of Food Security and Nutrition in the World (SOFI) 2020. Rome, Italy: FAO, IFAD, UNICEF, WFP and WHO.

3. Mpembele Sala-Diankanda D (2002) Dinámica demográfica y seguridad alimentaria ¿Qué estrategia para el siglo XXI? In Claves para el siglo. Editiones UNESCO. Editorial Crítica.

4. Kahn A, MGK, Rifkin MJ (2002) Biotenologías ¿Hacia un nuevo mundo feliz? In Claves para el siglo. Editiones UNESCO. Editorial Crítica.

5. Weaver CM (2014) Bioactive Foods and Ingredients for Health. Adv Nutr 5: 306S-311S

6. Caroline D (2015) Nourrir La Machine Humaine. Montreal; Kingston; London; Ithaca: McGill-Queen's University Press.

7. Khoo CS, Knorr D (2014) Grand Challenges in Nutrition and Food Science Technology. Front Nutr 1: 4

8. Shen J, Obin MS, Zhao L (2013) The Gut Microbiota, Obesity and Insulin Resistance. Mol Aspects Med 34: 39-58.

9. Jacques A (2019) Histoires de l'alimentation. Fayard.

10. Conlon M, Bird A (2014) The Impact of Diet and Lifestyle on Gut Microbiota and Human Health. Nutrients 7: 17-44.

11. UNESCO World Forum (2019) Parma Declaration. UNESCO.

12. Living Heritage, Culture Sector, UNESCO (2018) Basic Texts of the 2003 Convention for the Safeguarding of the Intangible Cultural Heritage. UNESCO.

13. Morin E (2008) La Complexité humaine. Champs essais, numéro 189. Flammarion.

14. Lewontin RC (2000) It Ain't Necessarily so: The Dream of the Human Genome and Other Illusions / by Richard Lewontin. London: Granta Books.

15. Santos BS (2009) Una epistemología del sur. CLACSO-Siglo XII ediciones.

16. Derrida J (1978) Writing and Difference. University of Chicago Press.

17. Lepick JA (1979) Writing and Difference: Alan Bass's Translation of Derrida's 'L'Ecriture et La Difference. Edited by Jacques Derrida and Alan Bass. CEA Critic 41: 31-33 
Citation: Martínez JL (2021) Epistemology of a New Era of Healthy Foods and the Construction of Social Myths. Int J Clin Nutr Diet 7: 158. doi: https://doi. org/10.15344/2456-8171/2021/158

Page 5 of 5

18. Lamboley R (2005) Derrida et la « différance » aux sources de notre culture. Revue d'éthique et de théologie morale 234: 47-62.

19. Weitzner D (2007) Deconstruction Revisited: Implications of Theory Over Methodology. Journal of Management Inquiry 16: 43-54.

20. Mouffe C (1996) Deconstruction and Pragmatism. Routledge.

21. Morin E (2014) Introduction à la pensée complexe. Points Essais. Points.

22. Pulido-Salgado M, Mena FAC (2021) Bringing Policymakers to Science Through Communication: A Perspective From Latin America. Front Res Metr Anal 6: 18.

23. Derrien M, Veiga $P$ (2017) Rethinking Diet to Aid Human-Microbe Symbiosis. Trends Microbiol 25: 100-112.

24. O'Hara AM, Shanahan F (2006) The Gut Flora as a Forgotten Organ. EMBO Rep 7: 688-693.

25. Ho N, Prasad V (2013) Probiotics, Prebiotics, Synbiotics and Naturally Fermented Foods: Why More May Be More. Ann Gastroenterol 26: 277-278.

26. Cifuentes A (2009) Food Analysis and Foodomics. J Chromatogr A 1216 7109.

27. Brouns F, Nieuwenhoven M, Jeukendrup A, Lichtenbelt WM (2002) Functional Foods and Food Supplements for Athletes: From Myths to Benefit Claims Substantiation through the Study of Selected Biomarkers. Br J Nutr 88: 177-186.

28. Senok AC, Ismaeel AY, Botta GA (2005) Probiotics: Facts and Myths. Clin Microbiol Infect 11: 958-966.

29. Sharif MK, Khalid R (2018) Chapter 1 - Nutraceuticals: Myths Versus Realities. In Therapeutic Foods, edited by Alina Maria Holban and Alexandru Mihai Grumezescu. Academic Press.

30. Rifkin J (2009) El siglo de la biotecnología. El comercio genético y el nacimiento de un mundo feliz. Bolsillo Paidós. Barcelona. España: Editorial Paidós.

31. Lesser LI (2015) Nutrition Myths and Healthy Dietary Advice in Clinica Practice. AFP Journal 91: 5.

32. Estrela S, Whiteley M, Brown SP (2015) The Demographic Determinants of Human Microbiome Health. Trends Microbiol 23: 134-141.

33. Garland R (1992) Thomas W. Gallant. Risk and Survival in Ancient Greece: Reconstructing the Rural Domestic Economy. Stanford: Stanford University Press. 1991. Pp. Xvi, 267. \$39.50." The American Historical Review 97: 11891189.

34. Secretaría del Medio Ambiente del Gobierno de la Ciudad de México (2021) Mercado del Trueque.

35. Phillips $L$ (2006) Food and Globalization. Annual Review of Anthropology 35: 37-57.

36. Mintz SW, Bois CMD (2002) The Anthropology of Food and Eating. Annual Review of Anthropology 31: 99-119.

37. Capozzi F, Bordoni A (2013) Foodomics: A New Comprehensive Approach to Food and Nutrition. Genes Nutr 8: 1-4.

38. León C, Cifuentes A (2020) 15 - Foodomics Evaluation of Genetically Modified Organisms. Chemical Analysis of Food.

39. Barker E (1953) Aristóteles, Politica. The Classical Review 3: 117-118.

40. Morin X, Daneman R, Zavortink M, Chia W (2001) A protein trap strategy to detect GFP-tagged proteins expressed from their endogenous loci in Drosophila. Proc Natl Acad Sci U S A 98: 15050-15055. 